\title{
Margaret McCartney: The NHS shouldn't have to pick up the bill for private screening tests
}

\author{
Margaret McCartney general practitioner
}

Glasgow

It had to happen eventually: Bluecrest Health Screening has sent me my very own invitation for one of its private health assessments.

The invitation included a venue, a date, and a request that I call them to organise a time. The company takes out full page advertisements in national newspapers, claiming that you can "Help avoid a stroke with your New Year Health MOT" and asking, "Why leave your health to chance when you can be in control?"

The company offers "Five free tests when you accept in the next 28 days." Its tests include body fat percentage; "hydration levels"; height, weight, and body mass index percentages; and a QRISK2 assessment. Customers are also offered a "prostate cancer test" or "ovarian cancer test" and a "standard health screen," which includes blood pressure, liver function, full blood count, ferritin, renal function, glucose, lipids, and electrocardiography. If you're over 50 you may also be offered an "exclusive extra free offer" of a lung function test that can "detect COPD before any symptoms are apparent."

Over the years I've been contacted by many people who told me that they, or a family member, had taken up this offer because they thought that it was recommended by their doctor or would save the NHS money. In fact, Bluecrest encourages patients to "take your report to your GP to discuss any readings that cause you concern."

This is an outrage. Bluecrest offers non-evidence based screening, advertises using false and misleading information, and implies that the NHS doesn't offer screening at all. It implies that not having the screening misses an opportunity to control your health, overlooking the fact that all patients can already see their own NHS professional for cardiovascular risk screening. Bluecrest can then put the work associated with false positives and anxiety back onto the NHS while walking away with the profit.

\begin{abstract}
Health screening advertisements should be independently vetted before publication or distribution, at cost to the advertiser
\end{abstract}

The Advertising Standards Authority (ASA) has upheld each of three aspects of my complaint about this company. ${ }^{1}$ Bluecrest will no longer be allowed to say that screening for peripheral arterial disease will reduce cardiovascular risk, and it can no longer advertise prostate specific antigen or CA-125 tests as "cancer tests."

This is a good result, but it's taken months, and I'd rather have spent that time doing other things. It's also not the first time a complaint about a Bluecrest advertisement has been found in breach by the ASA, and it doesn't deal with the longer term problems caused by screening of this sort.

Tackling these problems requires two actions. The first is that, given the risk to the public, health screening advertisements should be independently vetted before publication or distribution, at cost to the advertiser. The second is that companies that provide and promote health screening (and Bluecrest is just one of them) should be required to take out private insurance for follow-up of any non-UK National Screening Committee recommended tests-or be billed by the NHS for follow-up work.

bmj.com News Private company criticised over exaggerated screening claims (BMJ 2018;360:k654, doi:10.1136/bmj.k654)

Competing interests: See www.bmj.com/about-bmj/freelance-contributors/margaretmccartney.

Provenance and peer review: Commissioned; not externally peer reviewed. Follow Margaret on Twitter, @mgtmccartney

Advertising Standards Authority. ASA ruling on Bluecrest Health Screening Ltd. 31 Jan 2018. https://www.asa.org.uk/rulings/bluecrest-health-screening-ltd-a17-389426.html.

Published by the BMJ Publishing Group Limited. For permission to use (where not already granted under a licence) please go to http://group.bmj.com/group/rights-licensing/ permissions 